\title{
A diachronic view of the net longshore sediment drift during the Late Holocene at the Jequitinhonha River delta, Brazil, using numerical modeling
}

\author{
ABILIO C.S.P. BITTENCOURT ${ }^{1}$, JOSÉ M.L. DOMINGUEZ ${ }^{1}$, CLEMENTE A.S. TANAJURA ${ }^{2}$, \\ IRACEMA R. SILVA ${ }^{3}$ and LOUIS MARTIN ${ }^{4}$ \\ ${ }^{1}$ Laboratório de Estudos Costeiros/CPGG, Instituto de Geociências, Universidade Federal da Bahia, \\ Campus Universitário da Federação, Rua Barão de Jeremoabo, s/n, 40170-115 Salvador, BA, Brasil \\ ${ }^{2}$ Departamento de Física da Terra e do Meio Ambiente, Instituto de Física, Universidade Federal da Bahia/CPGG, \\ Campus Universitário da Federação, Rua Barão de Jeremoabo, s/n, 40170-115 Salvador, BA, Brasil \\ ${ }^{3}$ Núcleo de Estudos Hidrogeológicos e de Meio Ambiente, Instituto de Geociências, Universidade Federal da Bahia, \\ Campus Universitário da Federação, Rua Barão de Jeremoabo, s/n, 40170-115 Salvador, BA, Brasil \\ ${ }^{4}$ Instituto de Geociências, Universidade Federal da Bahia, Campus Universitário da Federação, \\ Rua Barão de Jeremoabo, s/n, 40170-115 Salvador, BA, Brasil \\ Manuscript received on April 22, 2010; accepted for publication on March 22, 2011
}

\begin{abstract}
Using numerical modeling, this work estimates sediment dispersion patterns caused by the incidence of waves in five distinct coastline contours of the Jequitinhonha River delta plain during the Late Holocene. For this study, a wave climate model based on the construction of wave refraction diagrams relative to the current boundary conditions was defined and assumed to be valid for the five coastlines. Numerical modeling from the refraction diagrams was carried out considering the angle of incidence and wave height along the coastline. This work has allowed us to reproduce past and current patterns of net longshore sediment drift defined by a conceptual model developed from the integration of sediment cores, aerial photograph interpretation, $\mathrm{C}^{14}$ datings and geomorphic indicators of longshore drift. These results show that, on average, current wave conditions in the east-northeastern Brazilian region seem to have remained characteristically the same from approximately 5100 years BP until the present time. This type of information can be important when attempting to simulate possible future situations in terms of the long-term general behavior of the east-northeastern Brazilian coastal region.
\end{abstract}

Key words: past and current longshore transport, wave refraction, numerical modeling, Holocene, Brazil.

\section{INTRODUCTION}

Numerical modeling is used to study the evolution of coastal systems because it facilitates the investigation of processes that have occurred in the past (Cowell and Thom 1994). Accordingly, as stated by Cowell et al. (1995), the degree to which a simulation can reproduce the features observed in nature is a measure of its success. However, it is important to understand that the

Correspondence to: Iracema Reimão Silva E-mail: iracema@pq.cnpq.br/irsilva@ufba.br confirmation of the results of a model does not necessarily prove its veracity, but merely does not invalidate it (Oreskes et al. 1994).

Based on numerical modeling performed on wave refraction diagrams and under current boundary conditions, Bittencourt et al. (2005) presented a model of sediment transport that reproduces, on a regional scale, the directions of net longshore drift along a coastal stretch of approximately $3000 \mathrm{~km}$ in length in the eastnortheastern Brazil. These directions were shown by these authors to correspond in large scale to those pro- 
posed by Dominguez et al. (1992) based on paleogeographic reconstructions, which have persisted in the east-northeastern Brazilian coast since the Late Quaternary. In general, such persistence seems to be basically related to the marked stability of the barometric high pressure of the South Atlantic cell, which causes the trade winds system generated within it to be markedly stable. This stability results in a pronounced consistency in the direction and velocity of these winds and, consequently, in the dispersion of sediments along the east-northeastern Brazilian coast (Dominguez et al. 1992). J.K. Guimarães and J.M.L. Dominguez (unpublished data) and Bittencourt et al. (2007a) used the same method utilized by Bittencourt et al. (2005) and the current boundary conditions to estimate via inverse numerical modeling the patterns of net longshore drift under different scenarios during the quaternary evolution of the São Francisco River delta (in the central part of the east-northeastern Brazilian coast) and Doce River delta (in the south part of the east-northeastern Brazilian coast), observing that these patterns were comparable to those estimated from paleogeographical reconstructions. Subsequently, Bittencourt et al. (2007b) used a similar approach in the São Francisco River mouth to explain the different erosive phases that historically have been occurring there.

The above results may mean that, on average, regarding the east-northeastern Brazilian coastal region, the current boundary conditions (waves and wind) seem to have maintained their characteristics at least since the Late Quaternary.

The objective of this study was to experimentally develop a numerical simulation to assess the scope of applicability of the method used by Bittencourt et al. (2005). In this way, it was used the using the current boundary conditions imposed by the incident ocean waves and the intensity and direction of surface winds to reproduce the sediment dispersion patterns along the east-northeastern Brazilian coast that have developed since the Late Quaternary. Therein, the Jequitinhonha River delta plain was studied (state of Bahia) (Fig. 1), whose development during the Late Holocene (Dominguez et al. 1987, 2009) has shown evolutionary particularities that are distinct from those of the Doce River, which has been studied by Bittencourt et al. (2007a).

\section{GEOLOGICAL - PHYSIOGRAPHIC SETTING}

Dominguez et al. $(1987,2009)$ have shown that the coastal plain associated with the Jequitinhonha River mouth is bounded by ancient cliffs carved in Miocene age deposits of the Barreiras Formation (Suguio and Nogueira 1999). This plain is composed of Quaternary deposits including regressive marine terraces, fluvial terraces and wetlands (Fig. 1).

These marine terraces, composed primarily of medium to fine terrigenous sands, can be classified as one of two types (Dominguez et al. 1987): a) Pleistocene terraces that are associated with the subsequent regression of a transgressive maximum dated from 123,000 years BP, and b) Holocene terraces that are associated with the subsequent regression of a transgressive maximum dated from 5100 years BP. These terraces can be differentiated, based on patterns of orientation and truncation of beach ridges present in the surface, into three different ridge systems. These systems were identified by these authors to be associated with three successive mouths occupied by the Jequitinhonha River during the Holocene, corresponding to rapid phases of emergence (5100 to 3800 years $\mathrm{BP}$, 3500 to 2700 years BP, and 2500 years BP to the present) and submergence (3800 to 3500 and 2700 to 2500 years BP) from sea level on the Brazilian east coast, as described by Martin et al. (2003). Thus, these short duration emergences resulted in the drowning of the river mouths, which can be associated with the change of the river's course by an avulsion process. New deltaic features were built in the new mouths occupied by the river during the submergences (Dominguez et al. 1987). Based on these data, these authors were able to reconstruct, in time and space, paleogeographical maps correlated to the aforementioned sea level oscillations (Fig. 2).

As for the sediment dispersion patterns along the coastline during the evolution of the Jequitinhonha River delta, Dominguez et al. (1987) conditioned their evolution model for this delta plain in the general direction of the net longshore drift of sediments from south to north, similar to that observed by others (Bittencourt et al. 2005, Dominguez et al. 2006) and assessed in the present study. Furthermore, for the current coast- 


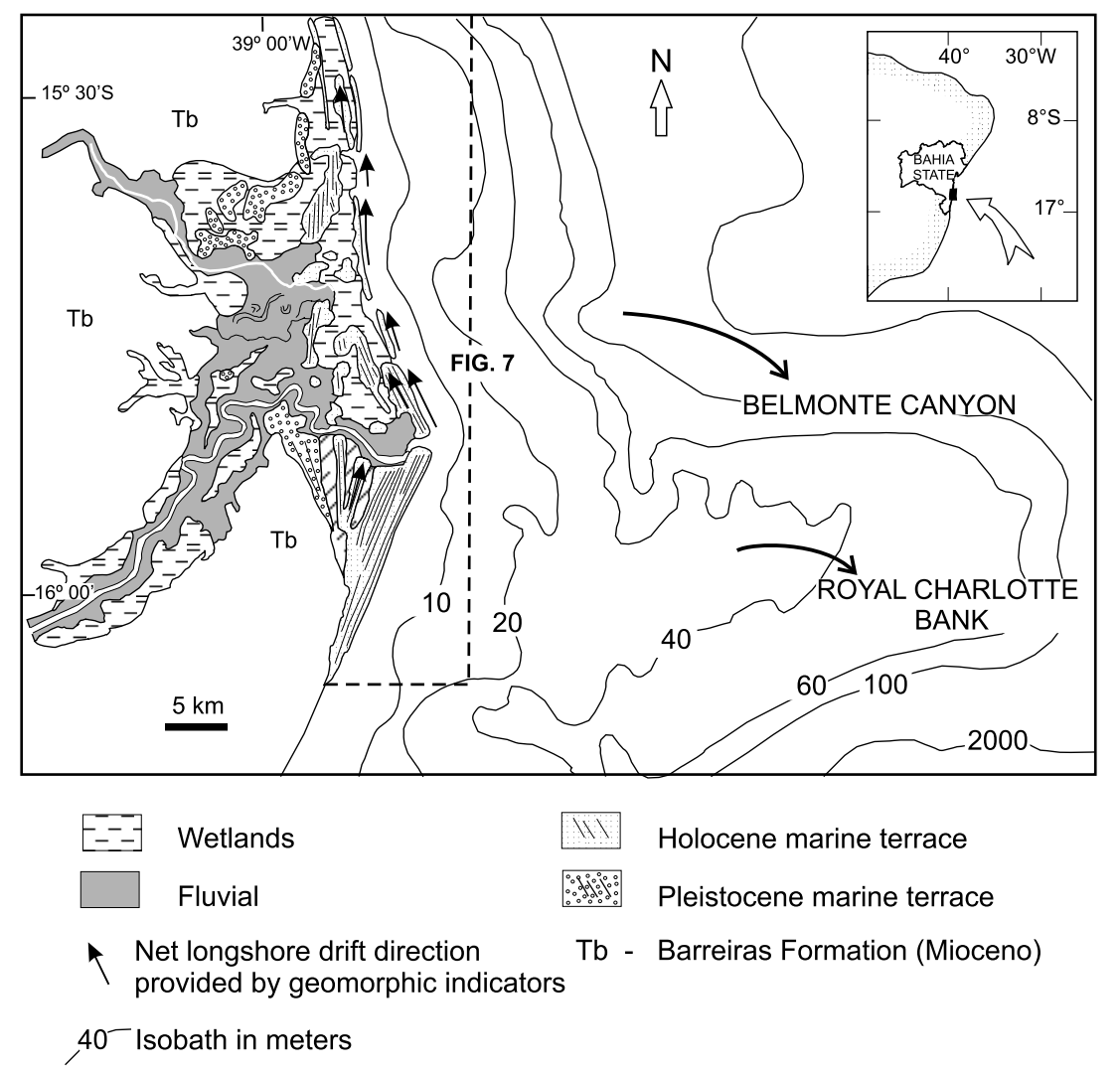

Fig. 1 - Geological map of the coastal plain associated with the Jequitinhonha River mouth and the morphology of the continental shelf (after Dominguez et al. 1987). Is also shown the limit of Figure 7.

line, which is composed primarily of medium to fine terrigenous sands, Dominguez et al. (2006) identified a divergence in the direction of the net longshore drift in the region of the most prominent deltaic cusp that is associated with the mouth. Several geomorphic indicators of longshore drift that point toward the north can be found in the northern half of the current coastline, whereas a single indicator in the southern half relative to the deltaic feature associated with the emergence phase between 3500 to 2700 years BP can also be observed pointing to the north (Dominguez et al. 1983, 1987) (Fig. 1).

The Jequitinhonha River (Fig. 1), a wave-dominated delta, drains into an area of approximately 66,000 $\mathrm{km}^{2}$, showing a deltaic area of about $800 \mathrm{~km}^{2}$. In the vicinity of its coastal plain, the continental shelf can be subdivided into two parts with well-distinguished characteristics. At the north of the mouth the continental shelf presents an average width of $26 \mathrm{~km}$, with isobaths that are generally parallel to the coastline. The mean slope in this section is on the order of $3 \mathrm{~m} / \mathrm{km}$, and its primary feature is the Belmonte Canyon. At the south of the mouth the shelf broadens, reaching a maximum of $105 \mathrm{~km}$. In this section, the primary feature is the Royal Charlotte Bank, which presents a flat surface with a mean slope of about $0.40 \mathrm{~m} / \mathrm{km}$. The shelf break occurs between the 60 and $80 \mathrm{~m}$ isobaths (França 1979).

\section{ATMOSPHERIC CIRCULATION ON THE SURFACE}

The study area is located within the South Atlantic trade wind belt associated with the anticyclone circulation around the South Atlantic Subtropical High (Bigarella 1972, Kousky and Chu 1978, Martin et al. 1998). This high has a strong quasi-stationary character, but has a well-defined seasonal cycle that imposes a change in direction and average wind intensity along the coast of the state of Bahia.

In order to characterize the mean wind conditions in the region of interest, climatological data were ob- 


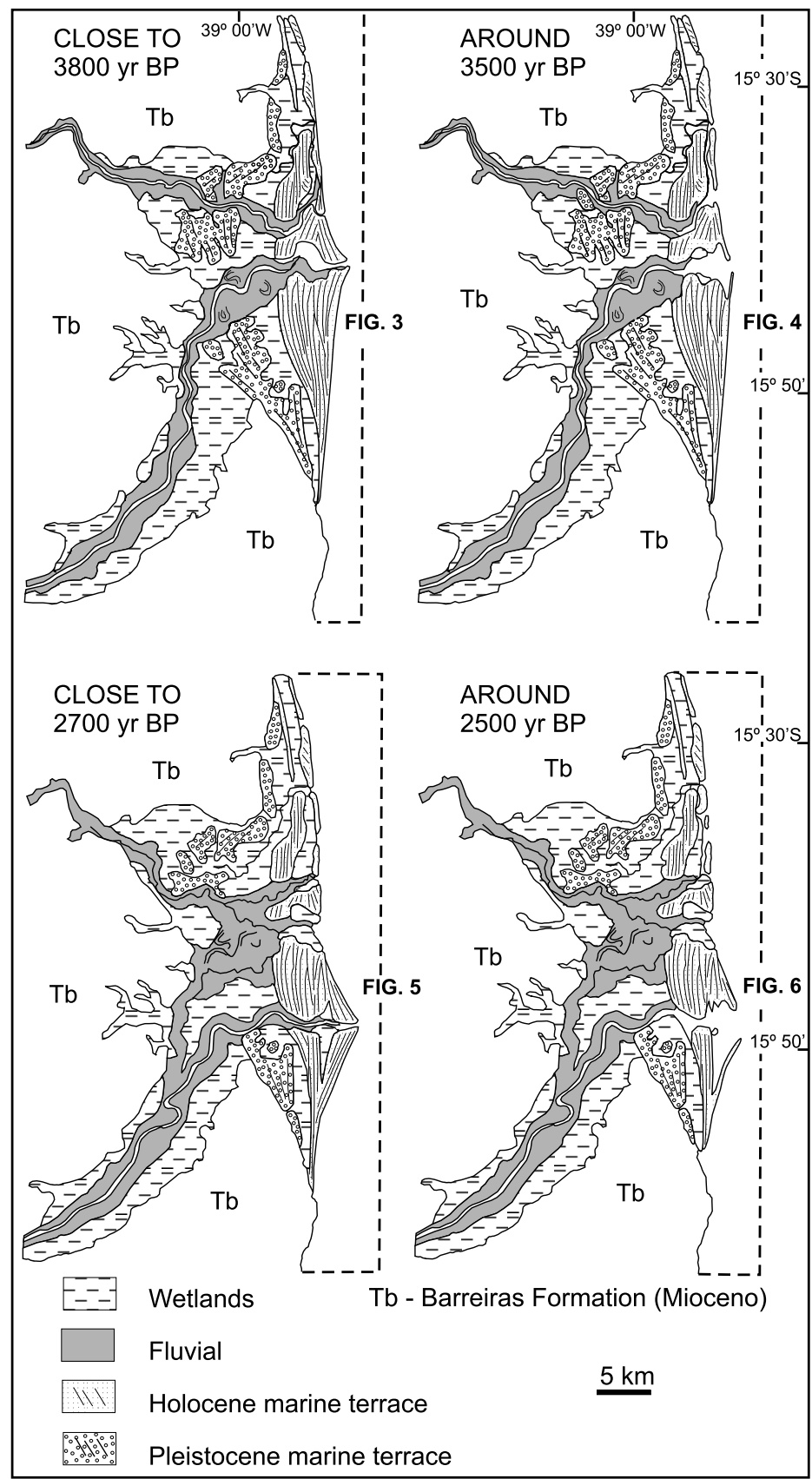

Fig. 2 - Paleogeographic maps of the coastal plain associated with the Jequitinhonha River mouth from 3800 to 2500 years AP (after Dominguez et al. 1987). The limits of Figures 3-6 are also shown.

tained using the surface winds and reduced pressure at sea level from global atmospheric analyses (based on a temporal series extending from 1948 to 2000) performed by the National Centers for Environmental Prediction (NCEP/NOAA), USA (Kalnay et al. 1996), available on their webpage [http://www.ncep.noaa.gov]. In the austral summer, the South Atlantic Subtropical High reaches its lowest average intensity during the year, around $1020 \mathrm{hPa}$, and its center is positioned more to the south, at $30^{\circ} \mathrm{S}, 5^{\circ} \mathrm{W}$. The winds in the coastal region in the south of Bahia State with latitudes higher than $15^{\circ} \mathrm{S}$ blow predominantly from the east-northeast, even- 
tually being altered to the southeast by traces of fronta systems that penetrate these low latitudes (Kousky 1979, Molion and Bernardo 2002). In the austral winter, the Subtropical High reaches its maximum intensity, around $1024 \mathrm{hPa}$, and its center is located a little more to the north and east, at approximately $28^{\circ} \mathrm{S}, 10^{\circ} \mathrm{W}$. The predominant winds from east-southeast are then modulated by the penetration of cold fronts with winds from south to southeast. The seasonal cycle of winds and subtropical highs change the average position of the divergence region of the surface windsin the Brazilian coast to approximately $13^{\circ} \mathrm{S}$ in the summer and $20^{\circ} \mathrm{S}$ in the winter.

\section{WAVE CLIMATE MODEL}

There are no direct wave measurements for the study area. The wave statistics (height and period) used in this study were extracted from Hogben and Lumb (1967). Considering that, along the east Brazilian coastal region, sea-type waves are much more common than swell-type waves (Davies 1972), which was confirmed by the wave statistics given in Hogben and Lumb (1967), wind current data were used to derive the frequencies regarding the wave fronts reaching the coastline. Therein, because winds and waves are subject to temporal and spatial variability in different scales, we considered the average directions of winds. In this same vein, Cowell and Thom (1994) and Hanson et al. (2003) pointed out that the dependence of winds and waves on the stochastic fluctuations becomes less important on geological scales (millennia) - covering the present study - in which coastal development occurs more often in response to trends in average environmental conditions. The average wind directions and frequencies used herein (the latter re-dimensioned to 100\%) (DHN 1993), which correspond to a time series from 1951 to 1972 and are able to generate waves in the direction of the coastline, are shown in Table I. The predominant periods and heights associated with these wave directions, also shown in Table I, were considered according to Hogben and Lumb (1967). It should be noted that the wave statistics used herein are uncertain due to the inaccuracy inherently present in the way in which they were obtained. This method relies on an observer's ability to determine some average height of the chaotic wave surface (Young and Holland 1996) from visual estimates in ships that usually follow standard routes. Based on these data, refraction diagrams were manually constructed according to procedures described in CERC (1984), resulting in a generic wave climate model for the study area. The bathymetric data used in the construction of these diagrams were extracted from a Brazilian Navy nautical chart on an approximate scale of 1:300,000. Refraction diagrams were constructed for the five distinct scenarios of shoreline position defined by Dominguez et al. (1987), from 5100 years BP until the present, as mentioned above (Figs. 1-2 and 3-7). The refraction diagrams constructed herein were based on current boundary conditions, had their wave-rays refracted to the $10 \mathrm{~m}$ isobath, and from there held their last propagation direction extending to different prior coastlines. No effort was made to rebuild the paleobathymetries because enough data were not available. Thus, we are conscious of the limitations of the data used, especially those pertaining to the current river mouth, wherein the isobaths clearly depict progradational geometry. In addition to the fact that, during the construction of the refraction diagrams, the attenuation of the wave energy by friction with the bottom was not considered, these limitations naturally give rise to more uncertainty about the sediment dispersion patterns described in this work. However, even with these limitations, it will be shown below that the modeling produced satisfactory results.

\section{DETERMINATION OF NET LONGSHORE DRIFT DIRECTION}

Considering the inadequacy of small-scale knowledge for the construction of long-term models, it is essential to eliminate noise that can be incorporated into the modeling that is indicative of the processes related to high frequency variables (Cowell et al. 1995, 2003, Larson et al. 2003, List and Terwindt 1995, Thieler et al. 2000). Thus, as indicated by De Vriend et al. (1993), for long-term (millennia) modeling, it is important to reduce information and use a small number of significant parameters that facilitate the interpretation and confirmation of the modeling. Furthermore, this procedure helps alleviate the uncertainty of the model (Terwindt and Battjes 1991, in Cowell et al. 1995). However, we should be aware that the greater the time involved, the greater the importance of historical contingency aspects. 


\section{TABLE I}

Wave direction, period and height of the studied area prepared from Hogben and Lumb (1967) data. The annual frequencies of the winds responsible for generating the waves (after DHN 1993) are also shown. These frequencies were used in the calculation of the net longshore drift.

\begin{tabular}{c|c|c|c}
\hline $\begin{array}{c}\text { Direction } \\
\text { of propagation } \\
\text { of the wave-front }\end{array}$ & $\begin{array}{c}\text { Wave period } \\
(\mathrm{sec} .)\end{array}$ & $\begin{array}{c}\text { Initial } \\
\text { deep water } \\
\text { wave height }(\mathrm{m})\end{array}$ & $\begin{array}{c}\text { Annual frequency } \\
\text { as deduced from } \\
\text { the wind record }\end{array}$ \\
\hline $\mathrm{NE}\left(\mathrm{N} 45^{\circ}\right)$ & 5.0 & 1.0 & 31 \\
$\mathrm{E}\left(\mathrm{N} 90^{\circ}\right)$ & 5.0 & 1.0 & 35 \\
$\mathrm{SE}\left(\mathrm{N} 135^{\circ}\right)$ & 6.5 & 1.5 & 21 \\
$\mathrm{SSE}\left(\mathrm{N} 157.5^{\circ}\right)$ & 6.5 & 1.5 & 13 \\
\hline
\end{tabular}

The direction of net longshore sediment drift was determined by the calculation of the potential intensity of longshore drift for each wave-front direction according to the method described in Bittencourt et al. (2005). This relatively simple method combines the minimum number of necessary parameters to achieve the goals of modeling. This approach considers that: a) the wave energy outside the breaker zone is directly proportional to the square of its height (Davies 1972, Munk and Traylor 1947), and b) the intensity of the longshore drift is proportional to the angle at which the wave-front strikes the coastline (Kokot 1997, Komar 1976, Zenkovitch 1967) according to the function (Komar 1976):

$$
Y=\sin a \cdot \cos a,
$$

where $Y$ is an intensity factor for the potential longshore drift, and a is the incidence angle of the wave orthogonal to the shoreline. Thus, the potential intensity of the longshore drift was expressed by a non-dimensional number according to the function:

$$
X=Y \cdot H^{2},
$$

where $X$ is the intensity of the longshore drift, and $H$ is the normalized wave height (i.e., the results were divided by a $1 \mathrm{~m}$ constant value). The wave height along the coastline was estimated according to the equation (Bascom 1954):

$$
H=H_{0}\left(b_{0} / b\right)^{1 / 2}
$$

where the subscript zero designates deep water conditions (Table I), and $b$ is the distance among adjacent sets of wave-front orthogonals. The coastline was divided into segments, each of them approximating a straightline, in accordance with the orientation of the coastline (Figs. 3-7). Eventually, a single straight-line segment was divided into two or more segments due to the presence of different distance patterns between the waverays, as in the case of segments 8 and 9 in Figure 4 (SE). The distances $b$ and $b_{0}$ (Figs. 3-7) were measured at the outer and inner limits of the wave orthogonals striking each shoreline segment or, rarely, when this was not possible, by assembling contiguous segments, as in the case of segments 7 and 8 in Figure 4 (SSE). Thus, a value for the average wave height was obtained along the coastline for each coastal segment considered. The angle a between each segment and a certain wave-front was the predominant one among the wave-rays striking that segment, and was directly measured in the refraction diagram (Figs. 3-7). Later, the value obtained for the drift intensity was multiplied by the percentage of the annual frequency of wind direction to which the wavefront under consideration is associated. In the coastal sections that presented opposing drift directions during the year, the direction of the longshore drift was defined concerning the predominant direction given by the difference of intensities among opposing drifts.

\section{RESULTS AND CONCLUSIONS}

Figures 3 to 7 present the directions of the net longshore sediment drift estimated in the present paper. It has been verified that, in the five modelled scenarios, the general direction of the drift is south to north, coinciding with the conceptual drift model of Dominguez et 


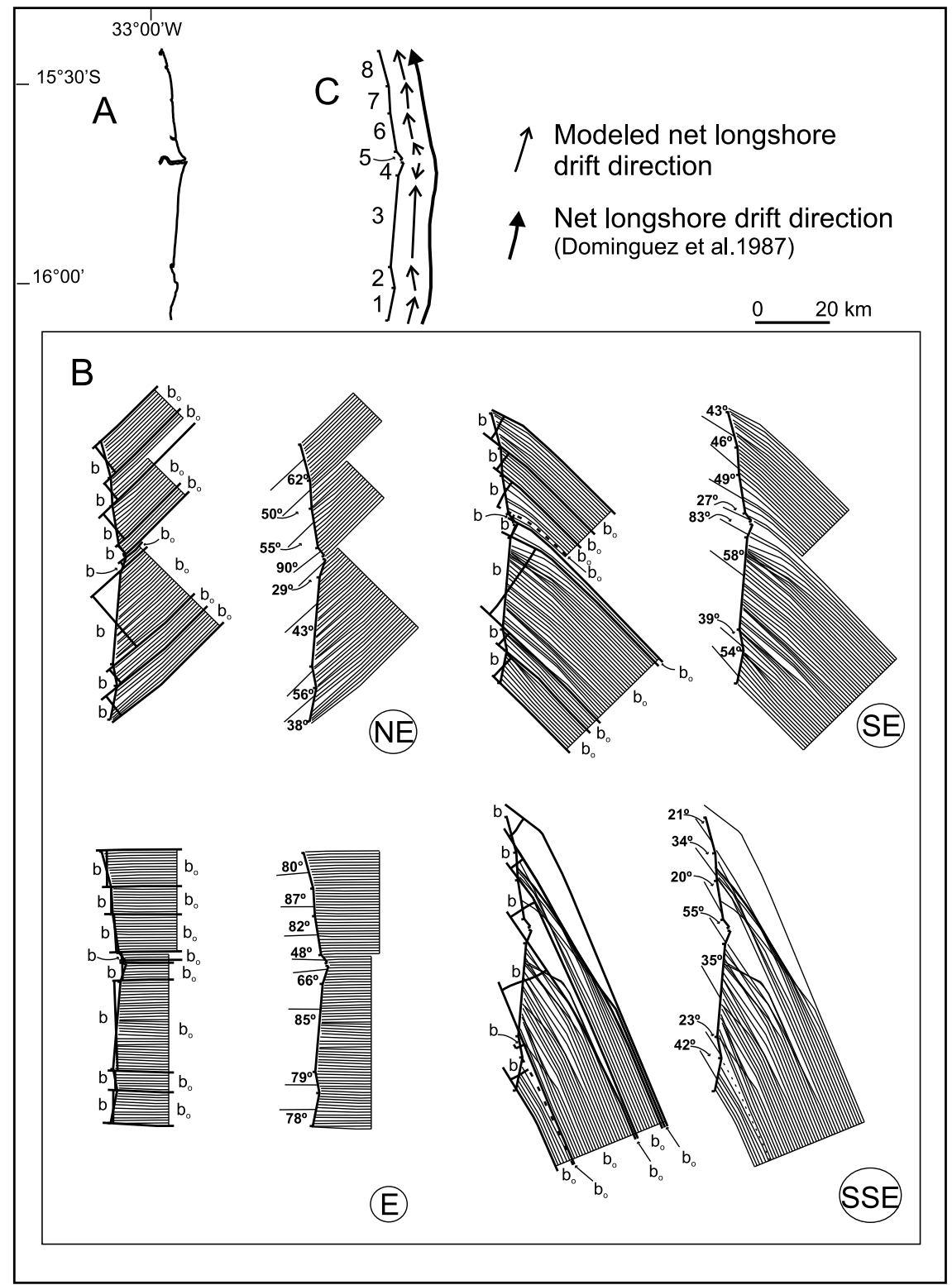

Fig. 3 - (A) Coastline in the Jequitinhonha River close to $3800 \mathrm{yr}$ BP (see also Fig. 2). (B) Refraction diagrams for waves with a $5 \mathrm{~s}$ period coming from northeast and east, and $6.5 \mathrm{~s}$ period coming from southeast and south southeast. The following are also shown: 1) different segments into which the shoreline was rectilinearized, 2) incidence angles formed by the wave-rays in relation to the coastal segments, and 3) measurements of $b$ and $b_{0}$ (see text) used to estimate wave height along the shore segments. (C) Rectilinearized segments showing the directions of net longshore sediment drift estimated from a) numerical modeling and b) Dominguez et al. (1987).

al. (1987) designed from paleogeographical reconstructions and, locally, with geomorphic indicators of longshore drift in the coastal plain. Exceptions to this pattern are observed during the progradation phases of the Jequitinhonha River delta, in the form of a small stretch of divergence in the drift direction, with the nodal point located at the apex of the delta cusp (Figs. 3, 5, and 7).
Such divergences, which are irrelevant to understanding the evolution of the coastal plain on the approximation scale of the model proposed by Dominguez et al. (1987), were not included. However, the presence of this local reversal in the drift direction is to be expected during the phases of delta development when the delta cusp becomes more prominent because of an increased load of 


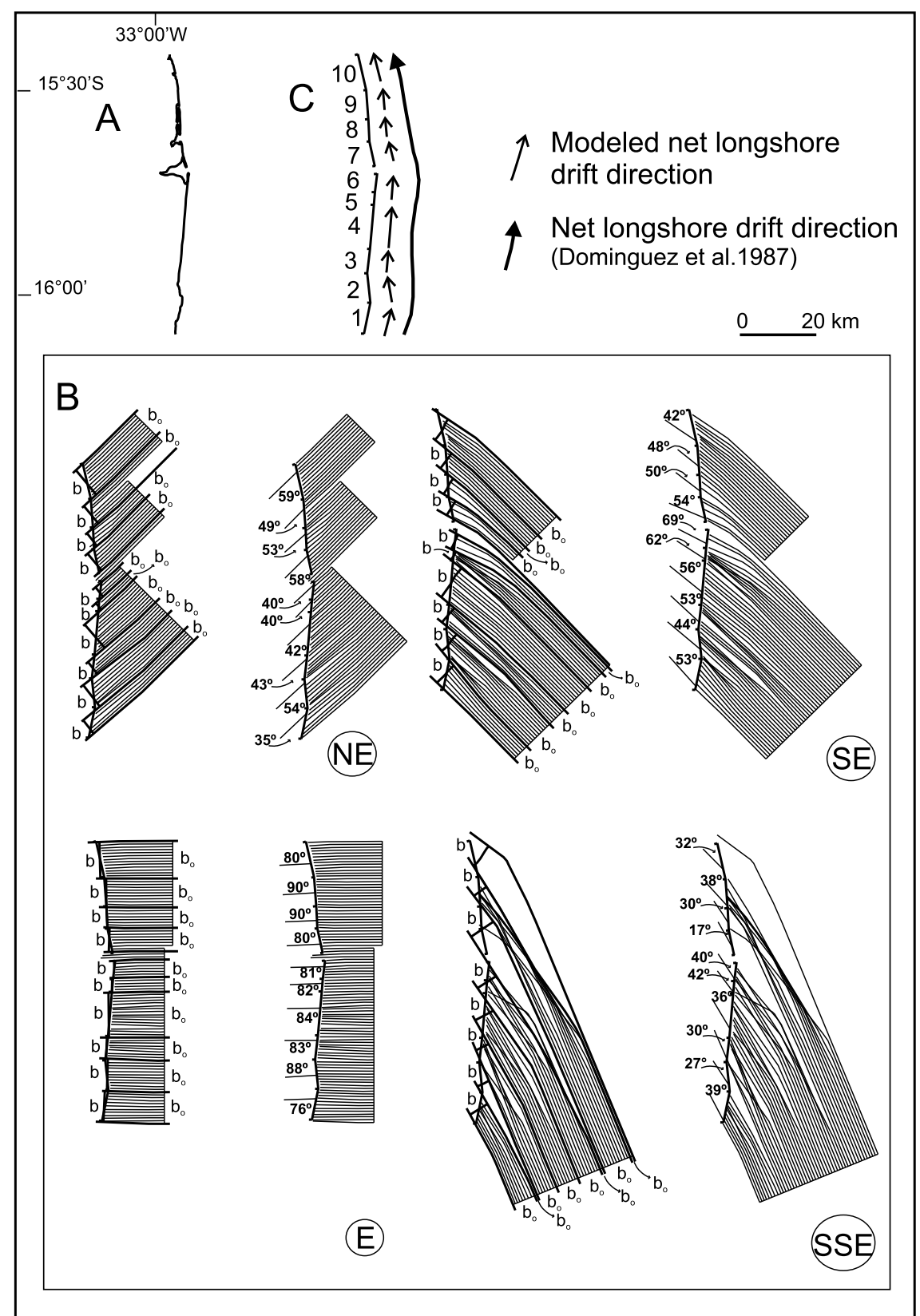

Fig. 4 - (A) Coastline in the Jequitinhonha River around $3500 \mathrm{yr}$ BP (see also Fig. 2). (B) Refraction diagrams for waves with a $5 \mathrm{~s}$ period coming from northeast and east, and $6.5 \mathrm{~s}$ period coming from southeast and south southeast. The following are also shown: 1) different segments into which the shoreline was rectilinearized, 2) incidence angles formed by the wave-rays in relation to the coastal segments, and 3) measurements of $b$ and $b_{0}$ (see text) used to estimate wave height along the shore segments. (C) Rectilinearized segments showing the directions of net longshore sediment drift estimated from a) numerical modeling and b) Dominguez et al. (1987).

sediments released by the river at the mouth (Pranzini 2001, Komar 1973). Locally, small changes may have occurred in sediment dispersion patterns related to morphodynamic adjustments linked to the development of bars associated with the river paleomouths.
Finally, we can conclude that, despite the different levels of uncertainty that arise from several limitations related to the methodology and the boundary conditions used herein and the simplified assumptions incorporated into the model, this work has allowed us to reproduce 


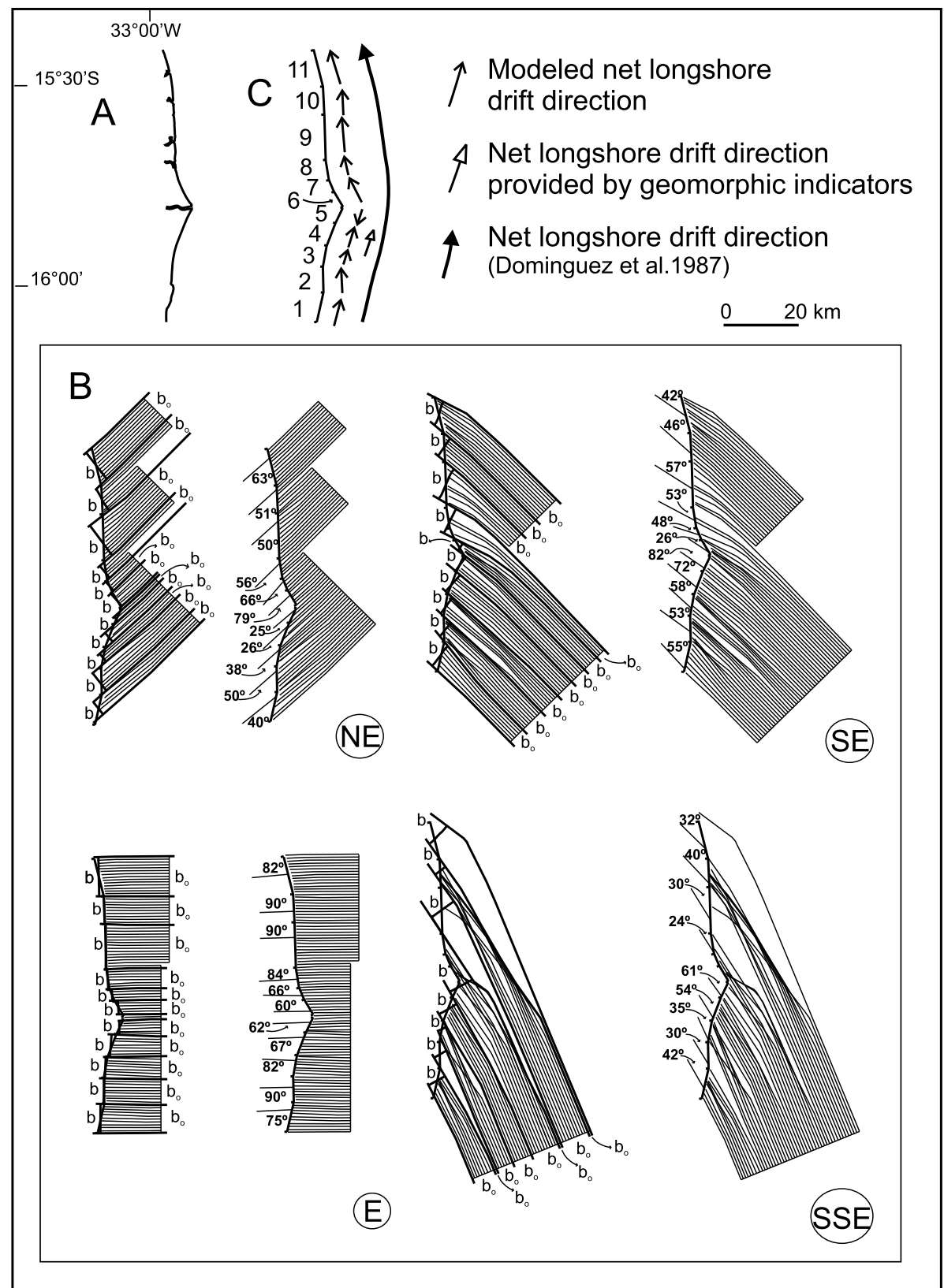

Fig. 5 - (A) Coastline in the Jequitinhonha River close to $2700 \mathrm{yr}$ BP (see also Fig. 2). (B) Refraction diagrams for waves with a $5 \mathrm{~s}$ period coming from northeast and east, and $6.5 \mathrm{~s}$ period coming from southeast and south southeast. The following are also shown: 1) different segments into which the shoreline was rectilinearized, 2) incidence angles formed by the wave-rays in relation to the coastal segments, and 3) measurements of $b$ and $b_{0}$ (see text) used to estimate wave height along the shore segments. (C) Rectilinearized segments showing the directions of net longshore sediment drift estimated from a) numerical modeling, b) Dominguez et al. (1987) and c) geomorphic indicators.

the past and present sediment dispersion patterns during the evolution of the Jequitinhonha River delta in the Late Holocene proposed by Dominguez et al. (1987), as well as those implicated by geomorphic indicators of longshore drift. Therefore, this fact reinforces the above view that, on average, in the east-northeastern Brazilian region, current wave conditions seem to have the same general characteristics from approximately 5100 years BP until the present time. This type of information, despite the uncertainties inherent in predic- 


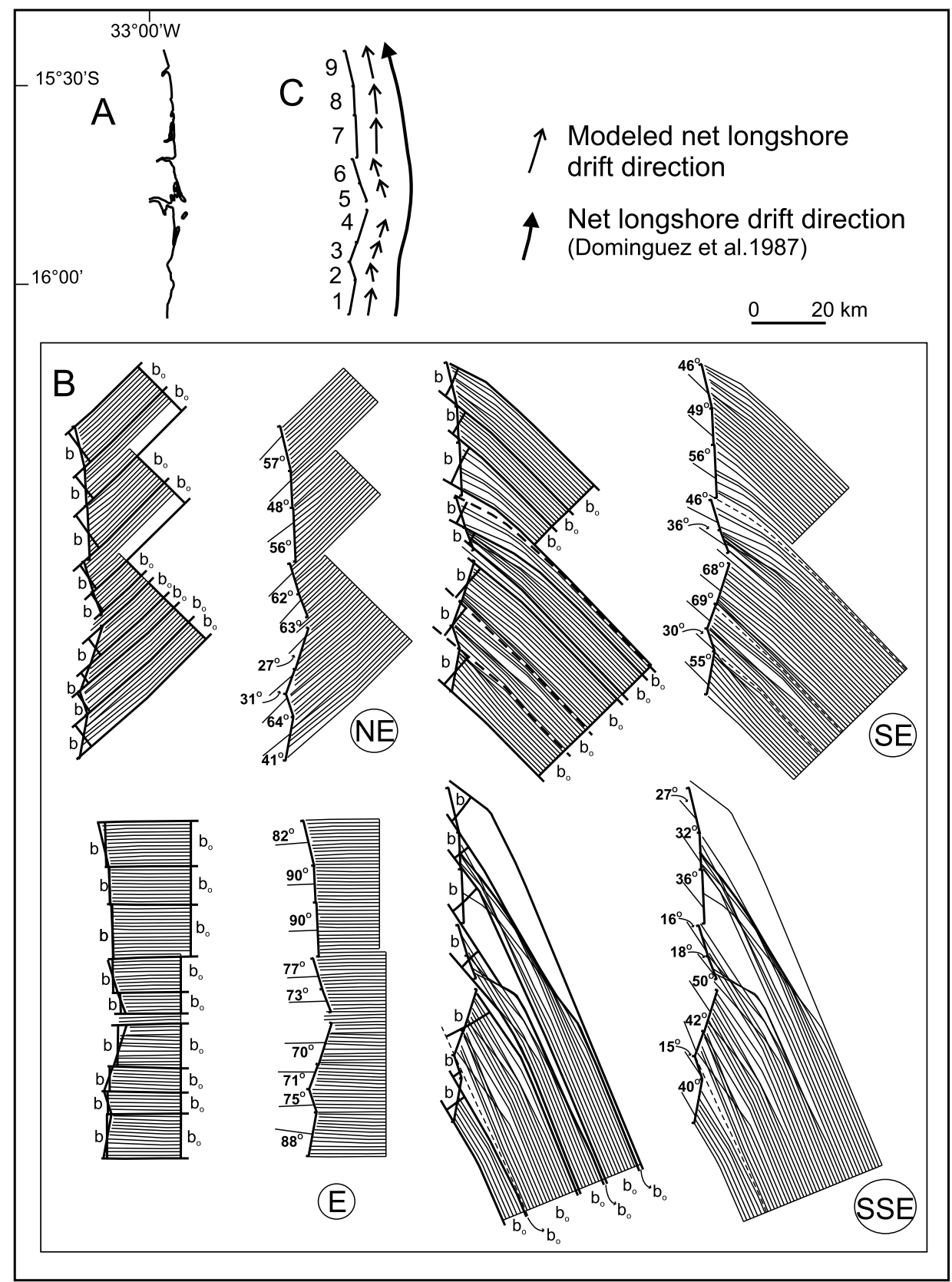

Fig. 6 - (A) Coastline in the Jequitinhonha River around $2500 \mathrm{yr}$ BP (see also Fig. 2). (B) Refraction diagrams for waves with a $5 \mathrm{~s}$ period coming from northeast and east, and $6.5 \mathrm{~s}$ period coming from southeast and south southeast. The following are also shown: 1) different segments into which the shoreline was rectilinearized, 2) incidence angles formed by the wave-rays in relation to the coastal segments, and 3) measurements of $b$ and $b_{0}$ (see text) used to estimate wave height along the shore segments. (C) Rectilinearized segments showing the directions of net longshore sediment drift estimated from a) numerical modeling and b) Dominguez et al. (1987).

tions of the coastal system evolution (Cowell and Thom 1994, Oreskes et al. 1994, Terwindt and Battjes 1991, in Cowell et al. 1995) and their greater complexity compared to inverse modeling (De Vriend 2003), may be important when attempting to simulate possible future scenarios. However, they leave out the chronological connotations of observing the general long-term behavior of the Brazilian coastal regions mentioned above. 


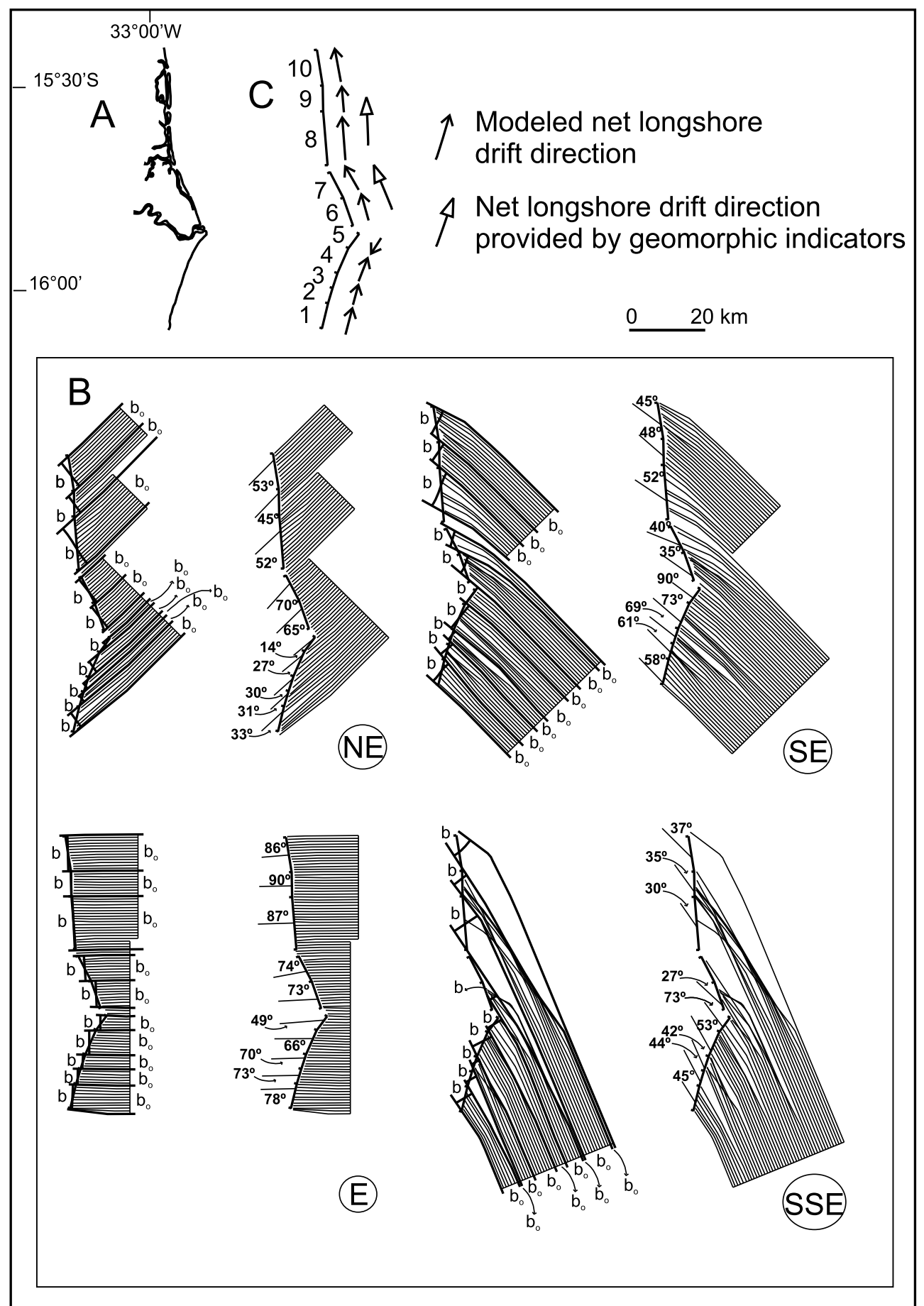

Fig. 7 - (A) Current coastline in the Jequitinhonha River (see also Fig. 1). (B) Refraction diagrams for waves with a $5 \mathrm{~s}$ period coming from northeast and east, and $6.5 \mathrm{~s}$ period coming from southeast and south southeast. The following are also shown: 1) different segments into which the shoreline was rectilinearized, 2) incidence angles formed by the wave-rays in relation to the coastal segments, and 3) measurements of $b$ and $b_{0}$ (see text) used to estimate wave height along the shore segments. (C) Rectilinearized segments showing the directions of net longshore sediment drift estimated from a) numerical modeling and b) geomorphic indicators. 


\section{ACKNOWLEDGMENTS}

A.C.S.P. Bittencourt, J.M.L. Dominguez, C.A.S. Tanajura and I.R. Silva thank Conselho Nacional de Desenvolvimento Científico e Tecnológico (CNPq) for the Research Fellowship Grant. We are also thankful to the Editorial Manager of Anais da Academia Brasileira de Ciências and one anonymous reviewer who have presented suggestions that helped to improve the paper.

\section{RESUMO}

O presente trabalho apresenta uma estimativa, por modelagem numérica, dos padrões de dispersão de sedimentos causados pela incidência de ondas em cinco distintos contornos de linhas de costa da planície deltaica do Rio Jequitinhonha durante o Holoceno Tardio. Para isso, um modelo de clima de ondas baseado na construção de diagramas de refração de onda, em função das condições de contorno atuais, foi definido e assumido ser válido para as cinco linhas de costa. A modelagem numérica, a partir dos diagramas de refração, foi feita considerando o ângulo de aproximação e a altura da onda ao longo da linha de costa. O trabalho permitiu reproduzir os padrões pretéritos e atuais da deriva litorânea efetiva de sedimentos, definidos por um modelo conceitual desenvolvido a partir da integração de testemunhos de sedimentos, interpretação de fotos aéreas e datações de $\mathrm{C}^{14}$, bem como por indicadores geomórficos de deriva. Estes resultados mostram que, em média, em relação à região leste-nordeste brasileira as condições de onda atuais parecem ter permanecido com as mesmas características desde aproximadamente 5.100 anos A.P. até o tempo atual. Esse tipo de informação pode ser importante para tentativas de simulação de possíveis situações futuras em termos do comportamento genérico de longa duração das regiões costeiras leste-nordeste brasileira.

Palavras-chave: transporte litorâneo passado e atual, refração de ondas, modelagem numérica, Holoceno, Brasil.

\section{REFERENCES}

BASCOM WJ. 1954. The Control of Stream Outlets By Wave Refraction. J Geol 62: 600-605.

Bigarella JJ. 1972. Eolian environments - Their Characteristics, Recognition and Importance. In: RIGBY JK AND HAMBLIN WL (Eds), Recognition of Ancient Sedimentary Environments. SEPM (special issue) 16: 12-62.

BitTencourt ACSP, Dominguez JML, Fontes LCS, Sousa DL, SILVA IR AND SILVA FR. 2007b. Wave Refraction, River Damming and Episodes of Severe Shore- line Erosion: The São Francisco River Mouth, Northeastern Brazil. J Coast Res 23: 930-938.

BitTencourt ACSP, Dominguez JML, Martin L AND SILVA IR. 2005. Longshore Transport on the Northeastern Brazilian Coast and Implications to the Location of Large Scale Accumulative and Erosive Zones: An Overview. Mar Geol 219: 219-234.

Bittencourt ACSP, Dominguez JML, Martin L, SiLVA IR AND MEDEIROs KOP. 2007a. Past and Current Sediment Dispersion Pattern Estimates Through Numerical Modeling of Wave Climate: An Example of the Holocene Delta of the Doce River, Espírito Santo, Brazil. An Acad Bras Cienc 79: 333-341.

CerC - Coastal Engineering Research Center. 1984. Shore Protection Manual. U.S. Army Corps of Engineers. Washington, DC, V.I., 597 p.; V. II, 603 p.

COWELl PJ, RoY PS AND JONES RA. 1995. Simulation of large-Scale Coastal Change Using a Morphological Behaviour Model. Mar Geol 126: 45-61.

Cowell PJ, Stive MJF, Niedoroda AW, De Vriend HJ, SWIFT DJP, KAMINSKY GM AND CAPOBIANCO M. 2003. The Coastal - Tract (Part 1). A Conceptual Approach to Aggregated Modeling of Low-Order Coastal Change. J Coast Res 19: 812-827.

Cowell PJ AND ThOM BG. 1994. Morphodynamics of Coastal Evolution. In: CARTER RWG AND WOODROFFE CD (Eds), Late Quaternary Shoreline Morphodynamics. Cambridge: Cambridge University Press, Great Britain, p. $33-86$.

DAVIES JL. 1972. Geographical Variation in Coastal Development. New York: Logman Inc., 204 p.

DHN - Diretoria de Hidrografia E NAVEgaÇão. 1993. Atlas de Cartas - Piloto. Oceano Atlântico, de Trinidad ao Rio da Prata, $13 \mathrm{p}$.

DE VRIEnd HJ. 2003. On the Prediction of Aggregated Scale Coastal Evolution. J Coast Res 19: 757-759.

De VRiend HJ, CApobianco M, Chester T, De Swart HE, LatteuX B And Stive MJF. 1993. Approaches to Long-Term Modeling of Coastal Morphology: A Review. Coast Eng 21: 225-269.

Dominguez JML, ANDRADE ACS, Almeida AB AND BitTEnCOURT ACSP. 2009. The Holocene Barrier Strandplains of the State of Bahia. In: DillenburG SP AND HesP P (Eds), Geology and Geomorphology of Holocene Coastal Barrier of Brazil. Springer Verlag. Lecture Notes in Earth Sciences 107: 253-285.

Dominguez JML, BitTencourt ACSP AND MARTIN L. 1983. O papel da deriva litorânea de sedimentos arenosos na construção das planícies costeiras associadas às desem- 
bocaduras dos rios São Francisco (SE/AL), Jequitinhonha (BA), Doce (ES) e Paraíba do Sul (RJ). Rev Bras Geoc 13: 98-105.

Dominguez JML, BitTencourt ACSP AND MARTin L. 1992. Controls on Quaternary Coastal Evolution of the East-Northeastern Coast of Brazil: Roles of Sea-Level History, Trade Winds and Climate. Sediment Geol 80: 213-232.

Dominguez JML, MARTin L And Bittencourt ACSP. 1987. Sea-level history and the quaternary evolution of the river mouth-associated beach-ridge plains along the east-southeast coast of Brazil: a summary. In: NUMMEDAL D, PILKEy DH AND HowARD JD (Eds), Sea-Level Fluctuation and Coastal Evolution. SEPM (special issue) 41: 115-127.

Dominguez JML, MARTin L AND BitTencourt ACSP. 2006. Climate Change and Episodes of Severe Erosion at The Jequitinhonha Strandplain, SE Bahia, Brazil. J Coast Res (special issue) 39: 1894-1897.

FrANÇA AMC. 1979. Geomorfologia da margem continental leste brasileira e da bacia oceânica adjacente. In: Hernani C (Ed), Geomorfologia da margem continental brasileira e das áreas oceânicas adjacentes. Rio de Janeiro: PETROBRAS/CENPES, Série Projeto REMAC, 7: $89-127$.

HANSON H ET AL. 2003. Modelling of Coastal Evolution on Yearly to Decadel Time Scales. J Coast Res 19: 790-812.

Hogben N AND Lumb FE. 1967. Ocean Wave Statistics. London: National Physical Lab., Ministry of Technology, $263 \mathrm{p}$.

KALnAY E ET AL. 1996. The NCEP/NCAR 40-year reanalysis project. Bul Am Met Soc 77: 437-472.

Kокот RR. 1997. Littoral Drift, Evolution and Management in Punta Médanos, Argentina. J Coast Res 13: 192-197.

Komar PD. 1973. Computer Models of Delta Growth due to Sediment Input from Rivers and Longshore Transport. Geol Soc Am Bul 84: 2217-2226.

Komar PD. 1976. Beach Process and Sedimentation. New Jersey: Prentice Hall, 429 p.

KoUSKy VE. 1979. Frontal Influences on Northeast Brazil. Monthly Weather Rev 107: 1142-1153.

KoUSKY VE AND CHU PS. 1978. Fluctuations in Annual Rainfall in Northeast Brazil. J Met Soc Japan 56: 457465 .
LARSON M, CAPOBIANCO M, JANSEN H, RÓZYÚSKI G, Southgate HN, Stive M, Wijnberg M And Hulscher S. 2003. Analysis and Modeling of Field Data on Coastal Morphological Evolution over Yearly and Decadal Time Scales. Part 1: Background and Linear Techniques. J Coast Res 19: 760-775.

LIST JH AND TERWINDT JHS. 1995. Large-scale coastal behavior. Mar Geol 126: 1-3.

Martin L, Dominguez JML And BitTenCourt ACSP. 1998. Climatic Control on Coastal Erosion During a SeaLevel Fall Episode. An Acad Bras Cienc 70: 249-266.

MARTIN L, Dominguez JML AND BitTENCOURT ACSP. 2003. Fluctuating Holocene Sea Levels in Eastern and Southeastern Brazil: Evidence from Multiple Fossil and Geometric Indicators. J Coast Res 19: 101-124.

MOLION LCB AND BERnARdo SO. 2002. Uma Revisão da Dinâmica das Chuvas no Nordeste Brasileiro. Rev Bras Met 17: 1-10.

Munk WH AND TRAYLOR MA. 1947. Refraction of Ocean Waves; A Process Linking Underwater Topography to Beach Erosion. J Geol 55: 1-26.

Oreskes N, Shrader-Frechette K and Belitz K. 1994. Verification, Validation and Confirmation of $\mathrm{Nu}-$ merical Models in the Earth Sciences. Science 263: 641646.

PrANZINI E. 2001. Updrift River Mouth Migration on Cuspate Deltas: Two Examples From the Coast of Tuscany (Italy). Geomorph 38: 125-132.

Suguio K And NogueIRA ACR. 1999. Revisão Crítica dos Conhecimentos Geológicos Sobre a Formação (ou Grupo?) Barreiras do Neógeno e o seu Possível Significado como Testemunho de Alguns Eventos Geológicos Mundiais. Geoc 18: 461-479.

Thieler ER, Pilkey Jr OH, Young RS, Bush DM AND CHAI F. 2000. The use of mathematical models to predict beach behavior for U.S. coastal engineering: a critical review. J Coast Res 16: 48-70.

Young IR AND Holland GJ. 1996. Atlas of the Oceans: Wind and Wave Climate. Oxford: Pergamon, 238 p.

ZENKovitch VP. 1967. Processes of Coastal Development. London: Oliver and Boyd, $738 \mathrm{p}$. 